\title{
Austrian gene food petition puts pressure on European partners
}

[MUNICH] Austria has become the latest focus of European opposition to biotechnology. Twenty per cent of the population turned out last week to sign a petition calling for a ban on genetically modified food and on patents on genetically modified plants and animals.

The action increases the pressure on the Austrian government to maintain its opposition to efforts by the European Union (EU), which it joined relatively recently, to provide a more sympathetic legal environment for the biotechnology industry.

The national petition, known as a Volksbegehren, was organized by the Austrian ministry of internal affairs after its initiators - a group of non-governmental organizations (NGOs) led by the environmentalist groups Greenpeace Austria and Global 2000 obtained the necessary support from eight members of parliament.

More than 1.2 million Austrians visited polling stations to sign the petition which made three demands: "No food from genetic laboratories in Austria", "No field trials of genetically manipulated crops in Austria" and "No patents on life".

The turnout was unexpectedly high - the second-highest in Austria's history of national petitions, and the highest ever for a grass-roots initiative. This has forced a quick response from the government, which is an uneasy coalition of Austria's two main parties, the centre-left Social Democrats and the centreright Austrian Popular Party.

Chancellor Victor Klima has called a summit meeting for next Monday, 28 April. Together with five cabinet ministers, he will discuss with representatives of the NGOs their list of 40 specific demands. These include toughening the approval procedures for genetic experiments and increasing the power of the ethical committees involved in the procedures. They also want the manufacturers of gene-manipulated products to have explicit liability if their products cause environmental damage or health problems.

The NGOs want a ban on the local production of foods containing genetically modified ingredients - a ban on the import of such foods is considered unenforceable - and a five-year moratorium on field trials of genetically modified crops.

The government's response to these demands could significantly influence EU policies on genetic engineering, particularly if it accepts a significant number of them. In

\section{US advisory panel backs ITER design}

[WASHINGTON] A US Department of Energy (DoE) advisory panel has endorsed the design of the International Thermonuclear Experimental Reactor (ITER), even though it acknowledges that the reactor may not achieve one of its original design goals, plasma ignition.

In a report last week to Martha Krebs, the director of energy research, the Fusion Energy Sciences Advisory Committee said it found "no insurmountable obstacles" to prevent the proposed $\$ 10$-billion reactor from achieving its objectives.

The panel said that the design represents a "sound basis" for the United States to continue its relatively small planned contribution to ITER's construction phase. But its report acknowledged that the machine may be unable to demonstrate controlled ignition and extended burn, one of the original objectives set by the four ITER parties in 1992.

Krebs acknowledged that the question surrounding the demonstration of controlled ignition "is the sensitive result from the study", pointing out that no-one disputes that the project represents "an important set of science experiments". She added: "The question is how will Congress receive that."

The House of Representatives Science Committee last week approved authorizing legislation to add \$15 million to DoE's \$225million request for fusion energy research in fiscal year 1998, after several years in which Congress has cut the fusion budget. The Appropriations Committee has yet to act on the budget request.

The Science Committee has asked for a report on the appropriate role of the US fusion community in ITER once the design phase is completed next year. It points out that there is no official indication from the ITER project group, nor from participating parties, on how they intend to proceed to the construction phase.

Robert Conn, dean of engineering at the University of California at San Diego, and chair of the ITER review panel, said fusion researchers would be "ecstatic" with the machine, whether it achieves ignition or not.

Asked by Krebs whether he believed that the design for ITER is worth the proposed annual US contribution of $\$ 50$ million, Conn responded, “at $\$ 50$ million it's a terrific bargain". He added: "We're getting off on the cheap".

David Kramer

\author{
IMAGE \\ UNAVAILABLE \\ FOR COPYRIGHT \\ REASONS
}

Food for thought: a selection of foodstuffs that use soya as a constituent ingredient.

early February, Austria imposed a temporary ban on imports of Ciba's genetically engineered maize, even though it had been licensed for import into the EU last year.

Under a clause in the EU's directive on the deliberate release of genetically manipulated organisms, a three-month ban is allowed if a member state can provide evidence of risk to the environment or health.

Austria argued that the crop presented a risk because it contains a marker gene conferring antibiotic resistance which it says could, in principle, be transferred to humans or animals. Luxembourg has since imposed a similar ban, and Italy has banned the growing of crops from the maize seeds.

A European-level committee is considering the Austrian claims and is due to deliver its verdict by 15 May, when the temporary ban expires. But as the Austrian report apparently cites no new evidence, the European Commission is likely to rule against Austria's appeal.

This could bring to a head simmering tensions in Europe over genetically engineered foods. Only two weeks ago, the European Parliament, fired by memories of the commission's alleged mishandling of bovine spongiform encephalopathy, chastised the commission for its recent decision to exclude genetically engineered seeds that have already been licensed - such as Ciba's maize - from new, interim rules requiring them to be labelled (see Nature 386, 532; 1997).

If Austria takes a hard line on genetic engineering, this could also influence the fate of the commission's draft directive on the legal protection of genetically engineered products. A previous attempt by the commission to win the support of the European Parliament for such a directive failed two years ago, partly because of ethical concerns. The new directive is scheduled to receive its first parliamentary hearing next month.

In Austria, environmentalists are claiming that the petition represents a significant victory. "The vote gives a clear signal to the government that the population does not want genetically engineered food," says Matthias Schickhofer of Greenpeace Austria.

Alison Abbott 